\title{
The Correlation Between Knowledge and Attitude of the Nurse Towards of Usage Personal Protective Equipment in General Hospital of Pandan
}

\author{
Rostianna Purba \\ Nurse Academy Program of Diploma III Central Tapanuli of Poltekkes Kemenkes Medan.
}

\begin{abstract}
The efforts of safety and the hazard control can be done in various ways, one of them is by using of or wearing personal protective equipment. The incident of infection at the hospital is one of the problems because it can threaten the health of the patient, medical staffs, and visitors. WHO explain that, about 2,5\% of medical staff around the world facing HIV exposure, about $40 \%$ facing Hepatitis $B$ exposure and Hepatitis $\mathrm{C}$ exposure and many other infection which produce from other the exposure are exist in develop country. This type of research is quantitative by correlation design. The population of this research are all of the nurse in General Hospital of Pandan about 105 persons, by sample about 39 nurses. The results of this study show that the majority of the respondents are using the personal protective equipment as many as 25 persons $(64,10 \%)$, Chi Square Test was obtained $p$ Value $0.004(p-<0.05)$, it means that there is a correlation between the knowledge of the nurse with the use of personal protective equipment. Based on the Chi Square Test was obtained $p$ Value $0.000(p-<0.05)$ there is a significant relationship between the attitude of the nurse and the use of personal protective equipment. It is recommended to the all nurses to be always use the personal protective equipment in accordance with standard operational procedures as a safety and hazard control effort.
\end{abstract}

Keywords:- Knowledge, Attitude, Nurse, Protective Equipment.

\section{INTRODUCTION}

Hospital as an institution of health service for society with its own characteristics which is influenced by the development of health science, technology advances, and socioeconomic life of the society which should continue to be able to improve higher quality and affordable services by the community in order to achieve the highest health standards (Ministry of Health RI, 2010). In law no 36 of 2009 concerning health, especially article 165: The managers of workplace are required to carry out all forms of health efforts through prevention, enhancement, treatment and recovery for workers. Based on this article, the manager of workplace in a hospital has an obligation to make workforce healthy. One of them is through health and safety efforts.
Safety and hazard control efforts can be done in various ways, one of them is by using personal protective equipment. Personal protective equipment is a device which is used to protect themselves or the body against the dangers of workplace accidents, where technically can reduce theseverity of work accidents that occur. Personal protective equipment does not eliminate or reduce existing hazards, this equipment only reduces the amount contact with the hazards by placing a barrier between the workforce and the source of the hazard (Suma'mur, 2009). Personal protective equipment is a device that has the baility to protect a person whose function is to isolate part or the wole body from otential hazards in the workplace(PER.08/MEN/VII/2010).

According to Harwasih (2008), there are several types of personal protective equipment which absolutely used by workers when doing jobs and when facing the dangers due to work, such as safety caps, safety shoes, gloves, respiratory protection, and safety belts. Types of personal protective equipment used must be in accordance with the potential hazards faced and in accordance with the body parts that need to be protected.

According to several studies the incidence of infectious diseases in hospitals is one of the problems because it can threaten the health of patients, health workers, amd visitors. WHO explain that $2,5 \%$ the health workers throughout the world face exposure to HIV, around $40 \%$ face exposure to Hepaptitis B and Hepatitis C, and most infections resulting from these exposure are in developing countries (Reda, et al 2010).

The reults of National Safety Council (NSC) report in 1988 showed that the incidence of accidencts in hospitals $41 \%$ much more than workerw in other industries. Cases that often occur are needle sticking, sprains, back pain, scratches/cuts, burns, and infectious disease and others (Sholihah, 2013). A number of cases in the report recived compensation to hospital workers, are sprains, strains: 52\%; contussion, crushing, bruisng: $11 \%$, cuts, laceration, punctures: 10,8\%; fractures: 5.6\%; multiple injuries: 2.1\%; thermal burns: 2\%; scratches, abrasions: $1.9 \%$; infections: $1.3 \%$; dermatitis: $1.2 \%$ and others $12.4 \%$ (Teguh, 2008).

In Israel, the number of highest prevalence of back injury among nurses is $(16.8 \%)$ compared to other industry workers. In Australia, among 813 nurses, $87 \%$ are ever got low back pain, prevalence $42 \%$ and in the US, injury 
incident of musculoskeleta 4.62/100 nurses per year. Back injury spend the biggest compensation cost, it is more than 1 million \$ per year. Especially in Indonesia, the research study about the dangers in hospital are still not described clearly, but it trusted that there are many complaints from the hospital workers, in accordance with the dangers which are exist in the hospital (National Safety Council (NSC) tahun 2008).

The study which is conducted in Public Hospital of Cianjur mentioned that the number of nurses whose having acupuncture injury and other sharp objects injury are quite high about $61.34 \%$ (Hermana, 2009). Medical workers are risk of exposure transmition of infectious disease through blone borne at the accident of ccupuncture injury such as HIV infectious, Hepatitis B and Hepatitis C (Efstathiou, et al 2011).

A nurse should give attention to compliance with the use of personal protective equipment in the workplace, because compliance with the use of personal protective equipment before taking medical procedure on patients is one of the efforts made to minimize the risks that occur and as a form safety and guarantees working when carrying out medical procedure. According to result of the Udin's report (2016) in Sari Asih Hospital found that the compliance of nurse in using of personal protective equipment are influenced by several factors, knowledge, behavior, action, good communication with the manager of Hospital and the available of personal protective equipment by the managers of Hospital. According to Khaeriyah studies (2012) resumed that the nurse who have good knowledge are much more using the personal protective equipment than the nurse who have litle knowledge, this condition is in relate with the theory which is explained that the more knowledge person has, the better level of awareness and discipline of a person in terms of receiving or implementing a message or information delivered (Dayakisni dan Hudaniah,2003).

The attitude of the nurse towards behavior in usage personal protective equipment in a study which is conducted by Udin (2012), showed that 19 nurses attitude' that were balanced between nurse behavior in using of personal protective equipment had a significant and balanced relationship between positive and negative attitudes. This is impacted on nurses behavior's in using self protection tools, in accordance with the theory of attitude which states that individual attitudes are the beginning of the realization of individual actions or behavior (Dayakisni dan Hudaniah,2003).

\section{RESEARCH METHOD}

This type of research is quantitaive using correlation design. The population in this study was all nurses in Public Hospital of Pandan as many as 105 persons, with total sample of 39 persons. The writer used questionnaire which is arrenged by herself according to literature of study in order to collect the data and form of Informed Consent. The knowledge questionnaire, the attitude about the use of personal protective equipment are given in the form of question. The attitude questionnaire is scored by Linkert scale, by scoring: Agree (A) and given score 2 and Disagree (D) is given score 1. The measurement of the using of personal protective equipment is by using observation paper. Validity test in value with statistic test by using Koefisien Korelasi Pearson Product Moment. All statements are valid with $\mathrm{r}$ counts more than 0.361 . Reability test are conducted by doing Crombach Alpha Test and obtained a reliable variable with a value of more than 0.6. The Bivariate data analaysis using the chi square test with confident interval (CI) $95 \%$ and $\alpha=0.05$.

\section{RESULTS AND DISCUSSION}

After conducted this research it is obtained the results as:

\section{A. Univariate Analysis}

\begin{tabular}{|c|c|c|}
\hline Knowledge & Frequency & Percentage\% \\
\hline Good & 23 & 59 \\
41 \\
\hline Tdequate & 16 & $\mathbf{1 0 0}$ \\
\hline
\end{tabular}

Tabel 1:- Frequency Distribution of Nurses Knowledge's in the Usage of Personal Protective Equipments in Public Hospital of Pandan $(\mathrm{n}=39)$

\begin{tabular}{|c|c|c|}
\hline Attitude & Frequency & Percentage\% \\
\hline Positif & 22 & 56.4 \\
Negatif & 17 & 43.6 \\
\hline Total & $\mathbf{3 9}$ & $\mathbf{1 0 0}$ \\
\hline
\end{tabular}

Table 2:- The Frequency Distribution of Nurses Attitude's in the Usage of Personal Protective Equipments in Public Hospital of Pandan $(\mathrm{n}=39)$ 
ISSN No:-2456-2165

\begin{tabular}{|c|c|c|}
\hline $\begin{array}{c}\text { The Use of } \\
\text { Personal Protective } \\
\text { Equipment }\end{array}$ & Frequency & Percentage \% \\
\hline Yes & 25 & $64,1 \%$ \\
No & 14 & $35,9 \%$ \\
\hline Total & $\mathbf{3 9}$ & $\mathbf{1 0 0}$ \\
\hline
\end{tabular}

Table 3:- The Distribution of Personal Protective Equipments in Public Hospital of Pandan ( $\mathrm{n}=39)$

\section{B. Bivariate Analysis}

\begin{tabular}{|c|c|c|c|c|c|c|c|c|}
\hline \multirow{3}{*}{ No } & \multirow{3}{*}{ Knowledge } & \multicolumn{4}{|c|}{ The Use of Personal Protective Equipment } & & & \multirow{3}{*}{$p$ Value } \\
\hline & & \multicolumn{2}{|c|}{ Yes } & \multicolumn{2}{|c|}{ No } & \multicolumn{2}{|c|}{ Total } & \\
\hline & & $\mathbf{F}$ & $\%$ & $\mathbf{F}$ & $\%$ & $\mathbf{F}$ & $\%$ & \\
\hline 1 & Good & 19 & 82.6 & 4 & 17.4 & 23 & 100 & 0.004 \\
\hline \multirow[t]{2}{*}{2} & Adequate & 6 & 37.5 & 10 & 62.5 & 16 & 100 & \\
\hline & Total & \multicolumn{2}{|c|}{25} & 14 & 35.9 & & 100 & \\
\hline
\end{tabular}

Table 4:- The Correlation between Nurses Knowledge's Towards The Usage of Personal Protective Equipment in Public Hospital of Pandan $(n=39)$

\begin{tabular}{|c|c|c|c|c|c|c|c|c|}
\hline \multirow{3}{*}{ No } & \multirow{3}{*}{ Attitudes } & \multicolumn{4}{|c|}{ The Use Of Personal Protective Equipments } & & & \multirow[b]{2}{*}{$p$ Value } \\
\hline & & \multicolumn{2}{|c|}{ Yes } & \multicolumn{2}{|c|}{ No } & \multicolumn{2}{|c|}{ Total } & \\
\hline & & $\mathbf{F}$ & $\%$ & $\mathbf{F}$ & $\%$ & $\mathbf{F}$ & $\%$ & \\
\hline 1 & Positif & 21 & 95.5 & 1 & 4.5 & 22 & 100 & 0.000 \\
\hline 2 & Negative & 4 & 23.5 & 13 & 76.5 & 17 & 100 & \\
\hline & Total & & 5 & 14 & 35.9 & & 100 & \\
\hline
\end{tabular}

Table 5:- The Correlation Between The Nurses Attitude's Towards the Usage of Personal Protective Equipments in Public Hospital Pandan $(\mathrm{n}=39)$

Table 1. shows that the majority respondents have good knowledge as many as 23 persons (59\%), and who have enough adequate knowledge as many as 16 persons (41\%). Table 2 shows that the majority responden who have positive attitude's towards the using of personal protective equipments are 22 persons $(56,4 \%)$ and the minority respondents who have negative attitude's towards the using of personal protective equipments are 17 persons $(43,6 \%)$. Based on table 3 it resulted that the majority respondents who use the personal protective equipments are 25 persons $(64.10 \%)$, and the minority respondents who did not use the personal protective equipment are 14 persons $(35,9 \%)$.

The result of bivariate analysis was obtained, based on table 4, shows that majority respondents have good knowledge about 23 persons (59\%) with the use of personal protective equipments are as many as 19 persons $(82.6 \%)$ and the respondents who did not use it are as many as 4 persons $(17.4 \%)$ dan the respondents who have adequate knowledge are as many as 16 persons $(41 \%)$ and by using the personal protective equipments as many as 6 persons $(37.5 \%)$ and the respondents who did not use the personal protective equipment are as many as 10 persons (62.5\%) and there is no respondents who have less knowledge about it. Based on the statistic result with Chi-Square Test it resulted $p$ Value $0.004(p-<0.05)$, it means that there is a correlation of the knowledge of nurse towards the use of personal protective equipment. Based on the table 5 it resume that the majority respondents have positive attitude as many as 22 persons $(56.4 \%)$ with the use of personal protective equipments as many as 21 persons $(95.5 \%)$, did not use the personal protective equipments is only 1 person $(4.5 \%)$, and the monority respondents who have negative attitudes' are as many as 17 persons (43.6\%) with the use of personal protective equipments are 4 persons (23.5\%), 14 persons are using the personal protective equipments $(35.9 \%)$. Based on statistic resume by $C h i$ Square Test it obtained $p$ Value $0.000(p-<0.05)$, it means that there is a correlation of the Nurses' attitude towards the use of personal protective equipments.

The Description of Nurses' Knowledge On The Usage of Personal Protective Equipments

The result of the study shows that the majority of respondents in Public Hospital Pandan have good knowledge as many as 23 persons (59\%) and who have adequate knowledge are as many as 16 persons $(41 \%)$. The result of this study is in line with the research of Wulandini (2016), it is obtained result that the nurses knowledge's 
about the personal protective equipments are amount 77.3 $\%$ (34 persons). This result is also relates to Rini's research (2016) in patient surgical medical ward PKU Muhammadiyah Hospital Gamping Sleman shows that most of the nurse have good attitude's 50 respondents $(73.5 \%)$.

Knowledge is the result of understand, and it occurs after some body does seeinh process through human five sense, they are sight, hearing, smell, touch and taste. Most of the knowledge are obtained by the human throuh sight sense and hearing sense (Notoadmojo, 2011). Basically, knowledge will always improve in relate with the experience process which are experienced by the human itself. The knowledges are also can be increased through some informations, such as from TV, Radio, Magazine, Newspaper and other electronik devices.

\section{$>$ The Nurses'Attitude Towards The Usage of Personal Protective Equipments.}

The result of the research shows that the majority respondents / nurses in Public Hospital Pandan have positive attitudes' on the using of personal protective equipments are as many as 22 persons (56.4\%), and the minority respondents who have negative attitude's on the using of personal protective equipments are as many as 17 persons $(43.6 \%)$. This result study is also related to research of (Yenni astute, 2018) which conducted research about the nurses' attitude on the compliance of the use personal protective equipments in ICU, it resulted that the majority of nurses attitude's are psoitive. This research is also related with Putra research (2012), it is obtained that as many as 58 respondents $(51,3 \%)$ nurses have positive attitude towards the use of personal protective equipments.

Attitude is feeling, thingking and tendecy of someone which is more or less tend to permanent about the certain aspects on their environment. The attitude is an evaluative bias towards a stimulus or object that impacts how a person deals with the object. Attitude on the daily life is reactions which are emosionally deals with social stimulus. Attitude is not action or activity, but predisposition action or activity. (alport (1954) explained that attitude have three major components, they are belive(idea and concept), emosional life or emotional evaluation through an object, and tendency to act (trend to behave). Those three components all together create complete attitude (total attitude).

According to the analysis of researchers Use of Personal Protective Equipment The results showed that the majority of respondents used personal protective equipment as many as 25 people $(64.10 \%)$, and the minority who did not use personal protective equipment as many as 14 people $(35.9 \%)$. The results of this study are in accordance with the research of Wulandini (2016), the results obtained that the actions of nurses in using PPE that is good at $63.6 \%$ (28 people). One of the basic precaution standards is the use of Personal Protective Equipment (PPE) or Personal Protective Equipment (PPE). PPE is a tool that has the ability to protect a person and serves to isolate part or the whole body from potential hazards in the workplace. PPE includes gloves, face shields / masks / eye glasses, protective covers / sturdy foot wear (MOH RI, 2011). Based on the analysis of researchers, the majority of nurses have used personal protective equipment by $64.10 \%$. This can be caused by several factors such as knowledge, attitude, availability of PPE and hospital policies. head, protective dress / apron, shoes.

\section{$>$ The Usage of Personal Protective Equipments}

The result of study shows that the majority respondents used the personal protective equipments about 25 persons $(64.10 \%)$, and the minority respondents who did not use personal protective equipments about 14 persons $(35.9 \%)$. This result of study is in accordance with Wulandini (2016), it was obtained that the actions of nurses in using personal protective equipments is in good level, it is about $63.6 \%$ (28 persons).

One of the basic standard precaution is the using of personal protective equipments (PPE). Personal Protective Equipments is one of device which has ability to protect somebody and functioning to isolate some or the whole body from the dangers in workplace. The personal protective Equipments covers, gloves, face shields/masker/eye glasses, headgear, protective dresses/clemks, safety shoes/sturdy foot wear (Health Ministry of RI, 2011).

Based on the researcher analysis, the majority of nurses have used the personal protective equipments about $64.10 \%$. It can be caused by several factors such as knowledge factor, attitude factor, the availability of the personal protective equipments and the rules of Hospital.

\section{$>$ The Correlation of Nurses' Knowledge Towards The Usage of Personal Protective Equipments.}

Based on the statistic resume by Chi-Square Test, it was obtained that $p$ Value $0.004(p-<0.05)$. It means that there is a significant correlation between the nurses knowledge's towards the using of personal protective equipments. Good knowledge determines the good usage of personal protective equipments. This result study is also in accordance with the Mardiana research (2017), which was obtained that there is correlation of the knowledge level of nurse with the nurses' knowledge towards the usage of personal protective equipments.

The knowledge is influenced by formal education factor. Knowledge is very closely related with education, where it is expected that by having higher level education then the person will have the broader knowledge also he/she has. But it is important to emphasize, it doesnot mean someone who has low level education absolutely has low level of knowledge too. Both those apsects will determine the attitude of someone, the more positive aspects and object he/she known, then it will lead to increasingly positive attitudes towards certain objects (Dewi \& Wawan, 2010). 
Based on the researcher analysis, there is correlation between the nurses' knowledge towards the usage of personal protective equipments, it caused by the majority nurses have Diploma Educational Background (DIII) of Nurse, so they have obtain sufficient knowledge about the usage of personal protective equipment.

\section{The Correlation of Nurses' Attitude With The Usage of} Personal Protective Equipments.

Based on the statistic resume with Chi Square Test it was obtained $p$ Value $0.000(p-<0.05)$. it means that there is a significant correlation between the nurses' attitude with the usage of personal protective equipments. The nurses attitudes' who are majority in positive determine the behave of the usage personal protective equipments. This result is also in accordance with the research.

The attitude is predisposisi for giving response to environment stimulus which can be start or guide the behave of person. Defintively attitude means a situation of soul and the situation of thinking which is prepared to give response towards one object which is organized through experience and also influence directly or indirectly on practically or in action (Notoatmodjo, 2012). Attitude as a form of evaluation or feeling reaction.

This research result is in accordance with Ningsih research (2018). It was obtained value result $\mathrm{p}=0.027$ shows that there is a correlation of attitude with the behavior of usage personal protective equipment on nurses of Public Hospital of Mamuju Regency on 2018. This research is also in line with Saputro study (2015), it told that there is a significant correlation between attitude with the usage of personal protective equipments.

In this research, most of the nurses who work in inpatient room of Pandan Public Hospital are having good attitude towards the usage of personal protective equipments, this is proven by the result of respondents answer sheet which are exist in the questionnaire about the attitude of the usage personal protective equipment, most of the respondents are agree to use the personal protective equipments when they are working and carrying out medical procedure treatment to the patient. From this research, it also can be found that there still many respondents who have less attitude through the usage of personal protective equipments and did not use the personal protective equipments on the basic of standard of usage personal protective equipments which is expected in inpatient room. It can be influenced by sevefal factors, one of them is the knowledge about personal protective equipments which owned by the nurse that can influence the nurses in behaving towards personal protective equipments which are available in inpatient room of Public Hospital of Pandan and the avaailability of the personal protective equipments in Pandan Public Hospital.

\section{CONCLUSION}

The majority of the respondents are using the personal protective equipment as many as 25 persons $(64,10 \%)$, Chi Square Test was obtained $p$ Value 0.004 (p-<0.05), it means that there is a correlation between the knowledge of the nurse with the use of personal protective equipment. Based on the Chi Square Test was obtained $p$ Value 0.000 ( $p$ $<0.05)$ there is a significant relationship between the attitude of the nurse and the use of personal protective equipment. It is recommended to the all nurses to be always use the personal protective equipment in accordance with standard operational procedures as a safety and hazard control effort.

\section{REFERENCES}

[1]. Almaki, M. J. (2012). The relationship between quality of work life and turnover intention of primary health care nurses in Saudi Arabia. BMC Health Service Research, 12, 314.

[2]. Bahaql, M. F. (2010). Pengaruh Gaya Kepemimpinan Terhadap Kepuasan Kerja dan Kinerja dengan Komitmen Organisasi Sebagai Varibel Intervening. Universitas Diponerogo.

[3]. Bahtiar, S. S. (2012). Manajemen Keperawatan dengan Pendekatan praktis. Jakarta: Erlangga.

[4]. Baumann, A. (2010). The impact of turnover and the benefit of stability in the nursing workforce. Geneva, Switzerland: International Council of Nurses.

[5]. Chenowett, L. J. (2010). A Systematic review of wgat factor attract and retain nurses in aged and dementia care. Journal of Clinical Nursing, 19, 156-167.

[6]. Efstathiou,et. al. Factors Influencing Nurses' Compliace with Standard Precaution in order to Avoid Ocupational Exposure to Microorganisms: A Focus Group Study.BMC Nursing, 10 (1): 1 - 12.2011

[7]. Hastono, S. (2012). Analisis Data Kesetan. Depok: Fakultas Kesehatan Masyarakat Universitas Indonesia.

[8]. Hayhurst. A., s. c. (2015). Work environmental factors and retention of nurses. International Journal Of Nursing Studies, 20(3):283-8.

[9]. Hermana, A.D. (2006). Faktor-faktor yang Berhubungan dengan Terjadinya Luka Tusuk Jarum atau Benda Tajam Lainnya Pada Perawat di Rumah Sakit Umum Daerah Cianjur. Tesis Dipublikasikan.Depok: Univesitas Indonesia.

[10]. Jones, A. (2015). Organizational commitment in nurses: is it dependent on age or education? Nursing Management Vol 21 : 29.

[11]. Jusuf. (2010). kajian terhadap kecendrungan turn over perawat di pelayanan kesehatan sint carolus. tesis FKM UI

[12]. Kreitner, R. d. (2014). Prilaku Organisasi, Edisi 9. Jakarta: Salemba Empat.

[13]. Marquis, B. \&. (2010). Kepemimpinan dan manajemen keperawatan: teori dan aplikasi (edisi 4). Jakarta: EGC. 
[14]. Moriarity, A. (2017). organizational commitment and turnover intent as moderated by demographics in nurses. Disertation. Capella University.

[15]. Moriarity, A. (2017). Organizational commitment and turnover intent as moderated by demographics in nurses. Disertation. Capella University.

[16]. Mosadeghrad, A. M. (2012). A study of the relationship between job satisfaction, organizational commitment and turnover intention among hospital employed. Health Service Management Research, 21, 211-227.

[17]. Mulyono, W. (2010). Tesis Hubungan Spiritualitas di Tempat Kerja (STK) dengan Komitmen Organisasi Perawat di Rumah Sakit Islam Fatimah Cilacap. Jakarta: Program Magister Keperawatan UI.

[18]. Notoatmodjo, S. (2012). Metodologi Penelitian Kesehatan. Jakarta: Rineka Cipta.

[19]. National Safety Council (NSC) tahun 2008

[20]. O'Brien-Pallas, L. D. (2010). Impact and determinants of nurses turnover : a pan-Canadian study. Jurnal of Nursing Management, 18, 1073-1086.

[21]. Robbin, S. \&. (2013). Prilaku Organisasi. Jakarta : Salemba.

[22]. Tarigan, V. \&. (2015). Empirical study relations job satisfaction, organizationalcommitment, and turnover intention. advances in management and Apllied Economics, 5 (2), 21.

[23]. Tourangeau, A. C. (2010). Determinants of hospital nurse intention to remain employed : broadening our understanding. journalof advances nursing, 66(1), 22-32.

[24]. Tzeng, H. (2002). The influence of nurses' working motivation and job satisfaction on intention to quit : an empirical investigation in taiwan. International Journal of Nursing Studies, 38 (8), 867-878.

[25]. Ulrich, D. e. (2016). The twenry-Firs Century Hr Organization. Human Resource Management , (47), No. 4:p. 829-850.

[26]. Yatnikasari, A. (2010). Hubungan Program retensi dengan Komitmen Organisasi di RSAB Harapan kita,. tesis FK UI 